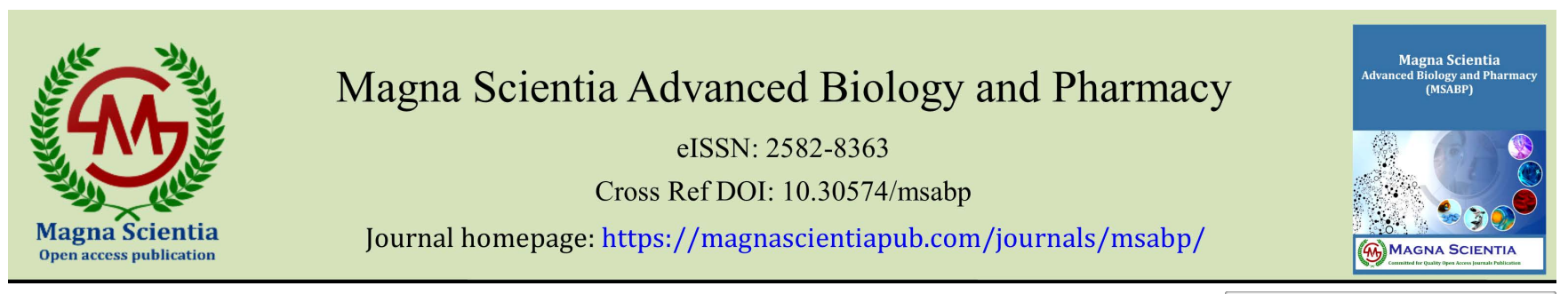

(RESEARCH ARTICLE)

\title{
Prebiotic activity of Indonesian black soybean (Glycine max (L.) Merr) anthocyanin
}

\author{
Rianita Pramitasari $1{ }^{*}{ }^{*}$, Felicia Roseline Sujonoputri ${ }^{2}$ and Diana Elizabeth Waturangi ${ }^{2}$ \\ ${ }^{1}$ Department of Food Technology, Faculty of Biotechnology, Atma Jaya Catholic University of Indonesia, Jl. Raya Cisauk- \\ Lapan No. 10, Tangerang, Banten, 15435, Indonesia. \\ 2 Department of Biotechnology, Faculty of Biotechnology, Atma Jaya Catholic University of Indonesia, Jl. Raya Cisauk- \\ Lapan No. 10, Tangerang, Banten, 15435, Indonesia.
}

Magna Scientia Advanced Biology and Pharmacy, 2021, 02(02), 037-041

Publication history: Received on 22 February 2021; revised on 26 March 2021; accepted on 28 March 2021

Article DOI: https://doi.org/10.30574/msabp.2021.2.2.0011

\begin{abstract}
Anthocyanins are well known have potential as a prebiotic source as they could increase the growth of probiotic bacteria and inhibit the growth of pathogenic bacteria. This study was conducted to obtain the prebiotic activity from Indonesian black soybean anthocyanin. Black soybean anthocyanin was extracted with $80 \%$ methanol $+1 \mathrm{M} \mathrm{HCl}$ solution under room temperature using a water bath shaker. In vitro prebiotic activity assay of anthocyanin extract was done using the spread plate technique to measure the growth of probiotic and pathogenic bacteria. Lactobacillus acidophilus was used as the probiotic bacteria, while Escherichia coli and Salmonella typhi were used as the pathogenic bacteria. The whole soybean flour and extract residue were used to compare with the prebiotic activity of the extract. The total monomeric anthocyanin content of the extract was $0.33 \mathrm{mg} / \mathrm{g}$. The highest prebiotic activity was obtained from anthocyanin extract, followed by the whole black soybean flour and anthocyanin extract residue, respectively. The prebiotic activity of the extract was higher compare with prebiotic activity standard $(>0.25)$. It could be concluded that Indonesian black soybean anthocyanin can be used as the source of prebiotic food.
\end{abstract}

Keywords: Anthocyanin; Black soybean; Prebiotic activity; black soybean

\section{Introduction}

Nowadays, the productive age people tend to pay more concern to the nutritional content contained in their food. Based on the results of a survey from Nielsen's Global Health 2016, as many as 80\% of respondents from Indonesia were more aware in the consumption of healthy food to prevent various diseases. The emergence of various degenerative diseases due to unhealthy lifestyles such as obesity, diabetes, and cardiovascular disease is one-factor driving people to start prioritizing their health and well-being to survive in this modern life. Various kinds of food contain functional compounds, such as vegetables, fruits, and foods containing prebiotics [1].

Prebiotic is a useful component to stimulate the growth and activity of beneficial bacteria in the human digestive system, especially in the large intestine, to maintain a healthy body. Prebiotic can be found in various source such as bananas, chicory root, Jerusalem artichoke, red onion, garlic, asparagus, barley, and nuts [2]. Black soybean is one of the foods which has high prebiotic potential due to the content of oligosaccharides, namely raffinose and stachyose [3].

Anthocyanins are the pigment that has benefits as an antioxidant [3]. Fotschki et al. [4] have reported that the content of oligosaccharides and anthocyanins in strawberries can increase the growth of probiotic bacteria in the digestive system of the rat. Black soybean also contains anthocyanins, and they accumulate in the outer skin layer of the epidermis

\footnotetext{
${ }^{*}$ Corresponding author: Rianita Pramitasari

Department of Food Technology, Faculty of Biotechnology, Atma Jaya Catholic University of Indonesia, Jl. Raya Cisauk-Lapan No. 10, Tangerang, Banten, 15435, Indonesia.
}

Copyright (C) 2021 Author(s) retain the copyright of this article. This article is published under the terms of the Creative Commons Attribution Liscense 4.0. 
[5] [6]. Research about the potential of prebiotic from anthocyanin of Indonesian black soybean is very limited. Therefore, the purpose of this study was to obtain the prebiotic activity of anthocyanin from Indonesian black soybean.

\section{Material and methods}

\subsection{Materials}

The materials used in this research were black soybean from Yogyakarta, Indonesia; methanol; $\mathrm{HCl}$; $\mathrm{pH} 1.0$ and 4.5 buffer solutions; Lactobacillus acidophilus ATCC@ 314; Escherichia coli ATCC® 25922; Salmonella typhi from Atma Jaya Catholic University of Indonesia culture collection; physiological salt (0.85\%); de Man, Rogosa, Sharpe Agar (MRSA) media; de Man, Rogosa, Sharpe Broth (MRSB) media; Nutrient Agar (NA) media; and Nutrient Broth (NB) media from Oxoid (UK). All chemicals were analytical grade obtained from Merck (Germany).

\subsection{Methods}

\subsubsection{Sample preparation}

Black soybean was ground into flour and sieved using a $53 \mu$ sieve, then stored at room temperature in an airtight plastic bag in dark condition before further assays.

\subsubsection{Anthocyanin extraction and analysis of total monomeric anthocyanin content}

Anthocyanin extraction was carried out following Shao et al. [7] with slight modifications. A total of $1 \mathrm{~g}$ of black soybean flour was extracted with $10 \mathrm{~mL}$ of $80 \%$ methanol solution containing $0.01 \mathrm{~mL}$ of $1 \mathrm{M} \mathrm{HCl}$ using a water bath shaker (Thermo Fisher, USA) for an hour at room temperature. Then, it was centrifuged (Eppendorf 5430, Germany) at 4500 rpm for 10 minutes at room temperature. The supernatant of the extract was separated from the residue then the solvents in extract and residue were evaporated using a rotary evaporator (Buchi R-300, Germany) at $37^{\circ} \mathrm{C}$.

The total monomeric anthocyanin content was analyzed used a differential pH method followed Oliveira et al. [8] with slight modifications. A total of $0.1 \mathrm{~mL}$ of sample was mixed with $6.4 \mathrm{~mL}$ of pH 1 and $\mathrm{pH} 4.5$ buffer solutions. The absorbance of the sample was measured at the wavelength of $514 \mathrm{~nm}$ and $700 \mathrm{~nm}$ using a UV-Vis spectrophotometer (Shimadzu, Japan). The calculation of total monomeric anthocyanin content (as mg cyanidin-3-glucoside equivalent per g dried weight) was done using the following formula:

$$
\begin{aligned}
& \qquad A=\left[\left(A_{514 n m}-A_{700 \mathrm{~nm}) \mathrm{pH} 1}\right]-\left[\left(\mathrm{A}_{514 \mathrm{~nm}}-\mathrm{A}_{700 \mathrm{~nm}}\right) \mathrm{pH} 4.5\right]\right. \\
& \text { Total monomeric anthocyanin content }=\frac{\mathrm{A}}{(\varepsilon \times \mathrm{L})} \times \mathrm{MW} \times \mathrm{DF}
\end{aligned}
$$

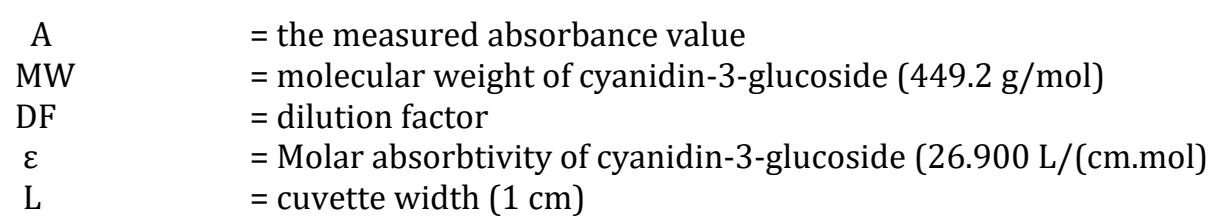

\section{Prebiotic activity assay}

The prebiotic activity was analyzed based on Huebner et al. [9] with slight modifications. L. acidophilus was streaked on MRSA then incubated at $37^{\circ} \mathrm{C}$ for 48 hours under anaerobic conditions in an anaerobic jar. For enteric bacteria, E. coli and $S$. typhi were streaked onto NA then incubated at $37^{\circ} \mathrm{C}$ for 24 hours. L. acidophilus which was grown on MRSA was transferred into $10 \mathrm{~mL}$ of MRSB and incubated at $37^{\circ} \mathrm{C}$ for 48 hours. While E. coli and S. typhi from NA were cultivated into $10 \mathrm{~mL}$ of NB and incubated at $37^{\circ} \mathrm{C}$ for 24 hours. Furthermore, $100 \mu \mathrm{L}$ of each enteric bacteria culture $(E$. coli and S. typhi) from NB were each transferred into $10 \mathrm{~mL}$ of $0.85 \%$ of $\mathrm{NaCl}$ physiological solution then incubated at $37^{\circ} \mathrm{C}$ for 24 hours.

For the treatment of anthocyanin extract, $0.5 \mathrm{~mL}$ of anthocyanin extract was added with $1 \mathrm{~mL}$ of media (MRSB for $L$. acidophilus and $0.85 \%$ of $\mathrm{NaCl}$ physiological solution for E. coli and S. typhi) and $20 \mu \mathrm{L}$ of bacterial culture. The sample was then resuspended and diluted until reached concentration of $10^{-2}$ and $10^{-3}$. A total of $100 \mu \mathrm{L}$ of each dilution was 
spread onto MRSA for L. acidophilus and NA for E. coli and S. typhi then incubated for 48 hours (L. acidophilus) and 24 hours (E. coli and S. typhi) at $37^{\circ} \mathrm{C}$.

For the treatment of anthocyanin extract residue, $0.5 \mathrm{~g}$ of residues was added with $1 \mathrm{~mL}$ of media (MRSB for $L$. acidophilus and $0,85 \%$ physiological salt for E. coli and S. typhi) and $20 \mu \mathrm{L}$ of bacterial culture. The sample was then resuspended and diluted until reached concentration of $10^{-2}$ and $10^{-3}$. A total of $100 \mu \mathrm{L}$ of each dilution was spread onto MRSA for L. acidophilus and NA for E. coli and S. typhi, then incubated for 48 hours (L. acidophilus) and 24 hours (E. coli and S. typhi) at $37^{\circ} \mathrm{C}$.

For the treatment of whole black soybean flour, $5 \mathrm{~g}$ of flour was added with $10 \mathrm{~mL}$ of media (MRSB for L. acidophilus and $0,85 \%$ physiological salt for E. coli and S. typhi) and $200 \mu \mathrm{L}$ of bacterial culture. The sample was then resuspended and diluted until reach concentration of $10^{-2}$ and $10^{-3}$. A total of $100 \mu \mathrm{L}$ of each dilution was spread onto MRSA for $L$. acidophilus and NA for E. coli and S. typhi, then incubated for 48 hours (L. acidophilus) and 24 hours (E. coli and S. typhi) at $37^{\circ} \mathrm{C}$.

The prebiotic activity was calculated using the equation below.

$$
\begin{aligned}
& \text { prebiotic activity }=\frac{\text { Probiotic } \log \frac{\mathrm{cfu}}{\mathrm{ml}} \text { on prebiotic } 48 \mathrm{~h}-\text { Probiotic } \log \frac{\mathrm{cfu}}{\mathrm{ml}} \text { on prebiotic } 0 \mathrm{~h}}{\text { Probiotic } \log \frac{\mathrm{cfu}}{\mathrm{ml}} \text { on control } 48 \mathrm{~h} \text { - Probiotic } \log \frac{\mathrm{cfu}}{\mathrm{ml}} \text { on control } 0 \mathrm{~h}} \\
& \text { prebiotic activity }=\frac{\text { Enteric } \log \frac{\mathrm{cfu}}{\mathrm{ml}} \text { on prebiotic } 48 \mathrm{~h} \text { - Probiotic } \log \frac{\mathrm{cfu}}{\mathrm{ml}} \text { on prebiotic } 0 \mathrm{~h}}{\text { Enteric } \log \frac{\mathrm{cfu}}{\mathrm{ml}} \text { on control } 48 \mathrm{~h} \text { - Enteric } \log \frac{\mathrm{cfu}}{\mathrm{ml}} \text { on control } 0 \mathrm{~h}}
\end{aligned}
$$

\subsubsection{Statistical analysis}

Data were statistically analyzed by IBM SPSS 22 using One-way ANOVA followed by Tukey's test at $p<0.05$.

\section{Results and discussion}

\subsection{Total monomeric anthocyanin content of Indonesian black soybean}

Based on the analysis, the total monomeric anthocyanin content obtained from Indonesian black soybean was 0.33 $\mathrm{mg} / \mathrm{g}$. Akond et al. [10] found that total anthocyanins content in black soybean was $0.14 \mathrm{mg} / \mathrm{g}$, this result showed higher compared with our study. A different result was also found from Žilić et al. [11] which were reported that total anthocyanins content in black soybean was $0.31 \mathrm{mg} / \mathrm{g}$ of, and this study showed lower compared with our study. The difference values between those value might happen due to the different planting environments of black soybean seeds, variety, sample preparation, as well as different extraction processes. On the other hand, other factors such as light, temperature, and plant management could also contribute the difference in anthocyanin content [12].

\subsection{Prebiotic activity}

Based on Table 1 the highest value of prebiotic activity was obtained from anthocyanin extract, followed by whole black soybean flour and the anthocyanin extract residue, respectively. This result was in line with Zhang et al. [13], which stated that anthocyanin could increase the growth of probiotic bacteria L. acidophilus. Anthocyanin could stimulate the production of digestive enzyme, namely $\beta$-glucosidase, in probiotic bacteria. The 3-glycoside bond in the anthocyanin will undergo a process of de-glycosylation by the enzyme, resulting in the breakdown of the heterocyclic ring and termination of the 3-glycoside bond, which will produce simple sugar or glucose. In this case, glucose molecules act as sources of energy and nutrients for the growth of probiotic bacteria [14]. Anthocyanin that undergoes a de-glycosylation process could also produce phenolic acids or organic acids, which have the same function to increase the activity of probiotic bacteria and have functioned as antioxidants that have many positive effects in maintaining body's health [13]. According to Fotschki et al. [4], anthocyanins found in strawberries could have a beneficial effect on the growth of probiotic bacteria. These probiotic bacteria could metabolize anthocyanins in human intestine and increase the production of short-chain fatty acids. These molecules were considered have good impact for large intestine due to the growth stimulation of probiotic bacteria as well as showed antimicrobial activity against enteropathogenic bacteria. Sun et al. [15] reported that anthocyanins from purple sweet potato could decrease the environmental $\mathrm{pH}$ so that they could increase the growth of probiotic bacteria. Research on anthocyanins from black soybean as prebiotics is still limited, 
therefore study on a specific mechanism of how anthocyanins from black soybean could stimulate the growth of probiotic bacteria and at the same time inhibit pathogenic bacteria are required for further research.

Table 1 The prebiotic activity of anthocyanin from Indonesian black soybean

\begin{tabular}{|l|l|l|}
\hline \multirow{2}{*}{ Sample } & \multicolumn{2}{c|}{ Prebiotic Activity } \\
\cline { 2 - 4 } & L. acidophilus to E. coli & L. acidophilus to S. typhi \\
\hline Anthocyanin extract & $1.05 \pm 0.03^{\mathrm{a}}$ & $1.05 \pm 0.03^{\mathrm{a}}$ \\
\hline Whole black soybean flour & $0.44 \pm 0.04^{\mathrm{b}}$ & $0.34 \pm 0.03^{\mathrm{b}}$ \\
\hline Anthocyanin extract residue & $0.24 \pm 0.04^{\mathrm{c}}$ & $0.29 \pm 0.02^{\mathrm{b}}$ \\
\hline
\end{tabular}

Anthocyanins derived from cranberry, bilberry, and blueberry fruit could inhibit the growth of $E$. coli and $S$. typhi due to structural changes, morphological damage, destruction of cell wall structures, membranes, and intracellular matrix of pathogenic bacteria. Anthocyanin could also cause cell deformation and inhibit enzyme activity by carrying out oxidation reactions in the sulfhydryl group or non-specific interactions with protein components, it causes the inactivation and function loses of the enzymes produced by pathogenic bacteria for their survival. Antimicrobial activities carried out by anthocyanins can occur due to various mechanisms and synergistic effects of various phytochemical components in anthocyanins, such as organic acids and phenolic acids [16] [17].

Black soybean flour performed lower prebiotic activity compared with anthocyanins extract, it might happen due to other components mixed together with anthocyanin in the flour including sugar, carbohydrates, and proteins. On the other hand, other compound in this mixture might disrupt the stability of anthocyanin and finally decrease its prebiotic activity. The anthocyanin extract residue showed the lowest prebiotic activity compared with others. Anthocyanin content in the residue extract was the lowest, since its only contained residue from extraction process. The lower the anthocyanin content of a sample, the lower its ability as a prebiotic. As a result, stimulation of microbiota growth becomes less effective [3] [18].

All three variations of the samples used in this study have the potential as good prebiotic sources. Vrese and Marteau [19] have reported that a food ingredient can be expressed as a good prebiotic source if the prebiotic activity against pathogenic bacteria value was above 0.25 . The value of prebiotic activity obtained in this study was different. It might happen due to the mechanism of induction of the growth of bacteria by prebiotics which is different and specific to each bacterial species. These factors also affect the value of prebiotic activity because bacteria have a different metabolic capacity. The use of anthocyanin as a prebiotic from bacteria also depends on the hydrolysis reaction and the transport system carried out by bacteria [20].

\section{Conclusion}

Anthocyanin extract from Indonesian black soybean performed the highest value of prebiotic activity followed by whole black soybean and residues from anthocyanin extract. From this study, anthocyanins are potential to be used as a prebiotic source as due to their role in stimulating growth of probiotic bacteria as well as inhibiting pathogenic bacteria. Indonesian black soybean has the potential as a prebiotic source because of its high anthocyanin content. However, further research is still required to explore the prebiotic activity using in vivo tests to reveal its efficacy in human health.

\section{Compliance with ethical standards}

\section{Acknowledgments}

The authors are thankful to Faculty of Biotechnology, Atma Jaya Catholic University of Indonesia, for funding support in this research.

\section{Disclosure of conflict of interest}

All the authors disclose no conflict of interest. 


\section{References}

[1] Priherdityo E. Survei: masyarakat indonesia mulai sadar makanan sehat [Internet]. Indonesia: CNNIndonesia; (C2016 [cited 2020 Jun 30]. Available from Survei: Masyarakat Indonesia Mulai Sadar Makanan Sehat (cnnindonesia.com).

[2] Lichteinstein GR, Gelsomin E, Vanderpool J. Gastrointestinal disease. In: Hark L, Morrison G, ed(s). Medical nutrition and disease: a case-based approach. Hoboken: Wiley-Blackwell. 2009; 278-311.

[3] Kurniasih N, Rosahdi TD, Rahman NR. Efektivitas sari kedelai hitam (Glycine soja sieb) sebagai bahan pangan fungsional. Jurnal Istek. 2013; 7(1): 52-82.

[4] Fotschki B, Juśkiewicz J, Jurgoński A, Kołodziejczyk K, Milala J, Kosmala M, Zduńczyk Z. Anthocyanins in strawberry polyphenolic extract enchance the beneficial effects of diets with fructooligosaccharides in the rat cecal environment. PLoS One. 2016; 11(2): e0149081.

[5] Jati IRAP, Vadivel V, Biesalski HK. Antioxidant activity of anthocyanins in common legume grains. In: Watson RR, Preedy VR, ed. Bioactive food as dietary interventions for liver and gastrointestinal disease. San Diego: Elsevier; 2013.

[6] Lee KJ, Lee JR, Ma KH, Cho YH, Lee GA, Chung JW. Anthocyanin and isoflavones contents in Korean black soybean landraces and their antioxidant activities. Plant Breed Biotech. 2016; 4(4): 441-452.

[7] Shao Y, Xu F, Sun X, Bao J, Beta T. Identification and quantification of phenolic acids and anthocyanins as antioxidants in bran, embryo, and endosperm of white, red, and black rice kernels (Oryza sativa L.). Journal of Cereal Science. 2014; 59: 211-218.

[8] Oliveira MAM, Moura MRL, Godoy RLO, Nele M, Deliza R, Vendramini ALA. Development of an acai-soymilk beverage: characterization and consumer acceptance. Braz. Journal of Food Technology. 2010; 3(4): 306-312.

[9] Huebner J, Wehling RL, Hutkins RW. Functional activity of commercial prebiotics. International Dairy Journal. 2007; 17: 770-775.

[10] Akond ASMGM, Khandaker L, Berthold J, Gates L, Peters K, Delong H, Hossain K. Anthocyanin, total polyphenols and antioxidant activity of common bean. American Journal of Food Technology. 2011; 6(5): 385-394.

[11] Žilić S, Akillihoğlu HG, Serpen A, Perić V, Gőkmen V. Comparisons of phenolic compounds, isoflavones, antioxidant capacity and oxidative enzymes in yellow and black soybeans seed coat and dehulled bean. European Food Research and Technology. 2013; 237(3): 409-418.

[12] Laleh GH, Frydoonfar H, Heidary R, Jameei R, Zare S. The effect of light, temperature, pH, and species on stability of anthocyanin pigments in four berberis species. PJN. 2006; 5(1): 90-92.

[13] Zhang P, Zhang M, He S, Cao X, Sun H, Chen X, Xie Y, Lou Q, Wang X, Ye Y. Extraction and probiotic properties of new anthocyanins form purple sweet potato (Solanum tuberosum). Current Topics in Nutraceutical Research. 2016; 14(2): 153-160.

[14] Hidalgo M, Concha MJO, Kolida S, Walton GE, Kallithraka S, Spencer JPE, Gibson GR, Teresa SDP. Metabolism of anthocyanins by human gut microflora and their influence on gut bacterial growth. Journal of Agricultural and Food Chemistry. 2012; 60: 3882-3890.

[15] Sun B, Hu C, Fang H, Zhu L, Gao N, Zhu J. The effects of Lactobacillus acidophilus on the intestinal smooth muscle contraction through PKC/MLCK/MLC signaling pathway in TBI mouse model. PLoS One. 2015; 10 (6): e0128214.

[16] Cisowska A, Wojnicz D, Hendrich AB. Anthocyanins as antimicrobial agents of natural plant origin. Natural Product Communications. 2011; 6(1): 149-156.

[17] Pojer E, Mattivi F, Johnson D, Stockley CS. The case of anthocyanin consumption to promote human health: a review. Comprehensive Reviews in Food Science and Food Safety. 2013; 12(2013): 483-508.

[18] Nikkah E, Khayamy M, Heidari,R, Jamee R. Effect of sugar treatment on stability of anthocyanin pigments in berries. Journal of Biological Sciences. 2007; 7(8): 1412-1417.

[19] Vrese MD, Marteau PR. Probiotics and prebiotics: effects on diarrhea. Journal of Nutrition. 2007; 137 (3):803-811.

[20] Anprung P, Sangthawan S. Prebiotic activity and bioactive compounds of the enzymatically depolymerized thailand-grown mangosteen aril. Journal of Food Research. 2012; 1(1): 268-276. 